\title{
Did a bi-polar multi-level oceanic oscillation cause the Little Ice Age and other high latitude climate extremes?
}

\author{
Robert G. Johnson \\ Department of Earth Sciences, University of Minnesota, Minneapolis, \\ Minnesota 55455
}

\begin{abstract}
Variations of ice-rafted sand and sediment from deep-sea cores beneath the North Atlantic Drift imply 1500yr cycles of the Drift flow and its associated climate warmth in northern North Atlantic regions. The Drift cycle is part of a complex bi-polar oceanic oscillation. Central to the oscillation is the relatively higher sea surface salinity of the high-latitude Greenland Sea that enables the winter sinking of surface water to form North Atlantic Deep Water (NADW). This drives the oscillation, and the NADW is replaced by water from the Drift. The oscillation causes climate extremes in both northern and southern high latitudes and is framed here in a sinusoidal model. The model is consistent with and may explain the early medieval climate optimum, the subsequent Little Ice Age, the recent record maximum area of Antarctic winter sea ice, and the related record low rate of Antarctic Bottom Water (ABW) formation. The negative feedback of lower salinity ABW entering the northern North Atlantic tends to inhibit NADW formation and the northward Drift flow. The positive feedback of warmer and higher salinity NADW mixing into the Southern Ocean around Antarctica tends to reduce sea ice formation and enhance the rate of ABW formation. Because of these feedbacks, the rate of NADW formation oscillates over a range less than a maximum without feedback, the rate of ABW formation oscillates over a range greater than a minimum without feedback, and the phase of NADW oscillation in the model leads the ABW oscillation by 375 years. The model predicts another northern North Atlantic climate optimum about $2500 \mathrm{AD}$. However, increases in penetration of the polar ocean by flow of Atlantic water in the process of replacing the sinking NADW suggest that an interval of extreme warmth in the northeastern North Atlantic may occur within decades. This penetration could result in the loss of perennial sea ice along the northern coast of Greenland. Much of the inferred increase of northward winter flow of northeastern North Atlantic water into the Greenland Sea in recent decades may be due to stronger NADW formation caused by greater salt contributions to the Drift from the Mediterranean outflow.
\end{abstract}

\section{Indexing terms/Keywords}

Little Ice Age; Oceanic oscillation; Deep-water formation; Antarctic climate; Medieval climatic optimum

\section{Academic discipline}

Paleoclimate

\section{Subject}

Natural Science

\section{Method/Approach}

Analysis and synthesis of data from studies of physical oceanography and climate that result in new climate change insights.

\section{Council for Innovative Research}

\section{Peer Review Research Publishing System \\ Journal of Advances in Natural Sciences}

Vol .3, No.1.

www.cirjns.com, editorinsonline@gmail.com 


\section{INTRODUCTION}

The great ocean conveyor[1] is a widely recognized broad description of the upper levels of world ocean circulation, driven primarily by sinking of denser saline water in the Greenland Sea to form NADW at intermediate depths of 2000$3500 \mathrm{~m}$. Part of the great conveyor, the North Atlantic Drift, feeds into the Norwegian Current, which in turn feeds into the Spitsbergen-Atlantic Current (SAC) that flows northward toward Spitsbergen to replace the sinking NADW (Fig. 1). In a seminal paper, Bond et al.[2] reported variations of ice-rafted sand and sediment in the northeastern North Atlantic that imply 1500yr cycles in the strengths of the Drift, the SAC flow, and NADW formation with corresponding climatic effects. However, the reality of the 1500yr higher latitude climate cycle has not been well confirmed in the Fennoscandian climate proxy record of Seppä and Birks[3], possibly due to overprinting of the proxies by random regional variations. The cause of a related climatic anomaly, the Little Ice Age, has also been vigorously debated. Proposed factors include solar variability and volcanic eruptions[4][5] and a change in thermohaline circulation[6]. Nevertheless, the Bond cycles are quite clear in the deep sea sediment record and can be integrated into a world-wide bi-polar oceanic oscillation that is consistent with observed major northern and southern high-latitude climate variations during the last 1000yrs.

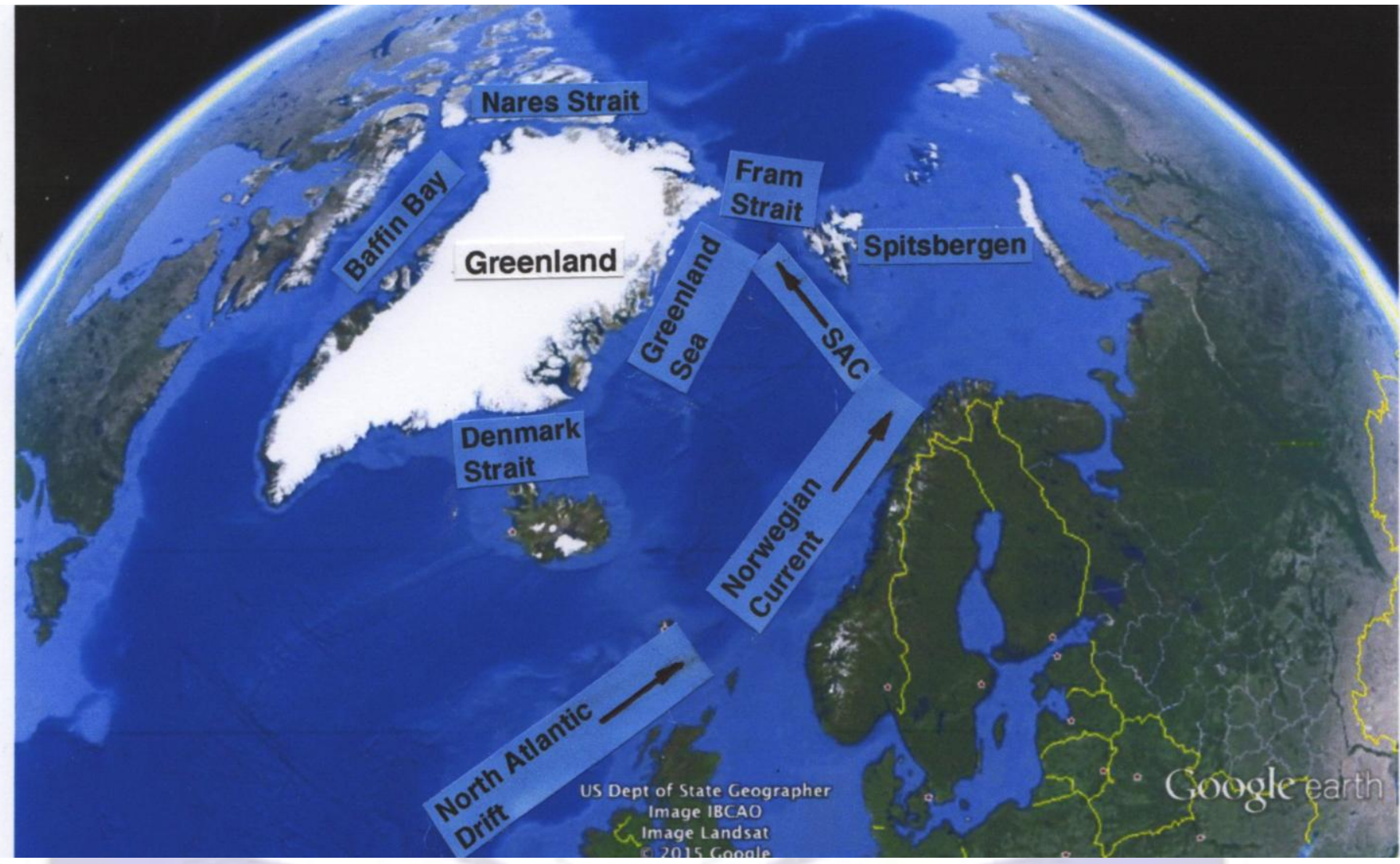

Fig. 1: Google Earth image of the Greenland Sea and vicinity showing the North Atlantic Drift, the Norwegian Current, and the Spitsbergen-Atlantic current (SAC), which flows northward to replace the water that sinks in the Greenland Sea to form North Atlantic Deep Water.

\section{[1] THE OCEANIC OSCILLATION}

\section{[1.1] Bi-polar feedbacks in the oscillation}

The main elements of the feedback loop are shown in Figure 2. NADW that sinks in the Greenland Sea is a key part of the oscillation loop. The sinking water mixes and circulates southward in the western North Atlantic. It eventually enters the Southern Ocean and joins the deep circumpolar current. The introduction of slightly warmer and saltier NADW into the Southern Ocean is positive feedback because it indirectly enhances the production of ABW. This lower-salinity ABW provides negative feedback for NADW production when it enters the northern North Atlantic at a present rate estimated by Wright to be between 1 and $3 \times 10^{6} \mathrm{~m}^{3} \mathrm{sec}^{-1}$ or $1-3 \mathrm{sv}[7]$. Higher trace amounts of dissolved silica in surface water found west of Scotland as reported by Reid[8] suggest that ABW mixes into the upper levels in the eastern North Atlantic. This is probably a geostrophic effect caused by the higher velocity of the subsurface northward flow off the west coasts of the British Isles calculated by Greatbatch and $\mathrm{Xu}[9]$. The lower salinity of the ABW component tends to reduce the salinity of the Drift, thus inhibiting NADW production, Drift flow, and its northward heat transport. Consequently, we have a large oscillating oceanic system involving bi-polar feedbacks, the ABW in the deepest world ocean at $\sim 4000 \mathrm{~m}$-depth, and the NADW in mid level water of the Atlantic and Southern Oceans at 2000-3500m. The delayed effects due to 
accumulation times enable the oscillations of the system. Using a sinusoidal model, this paper describes details of the oscillation and its climatic effects.

\section{[1.2] Key factors in the oscillation}

North Atlantic surface water has the highest salinity of the world's major oceans, and the higher salinity of sinking surface water in the Greenland Sea is required for the oscillation. The sinking rate depends directly on the density increase when cooled. The rate is therefore a function of the winter temperature and the salinity of the surface water, which is supplied by the North Atlantic Drift to the Norwegian Current and then to the Spitsbergen-Atlantic Current (SAC). The salinity of the Drift

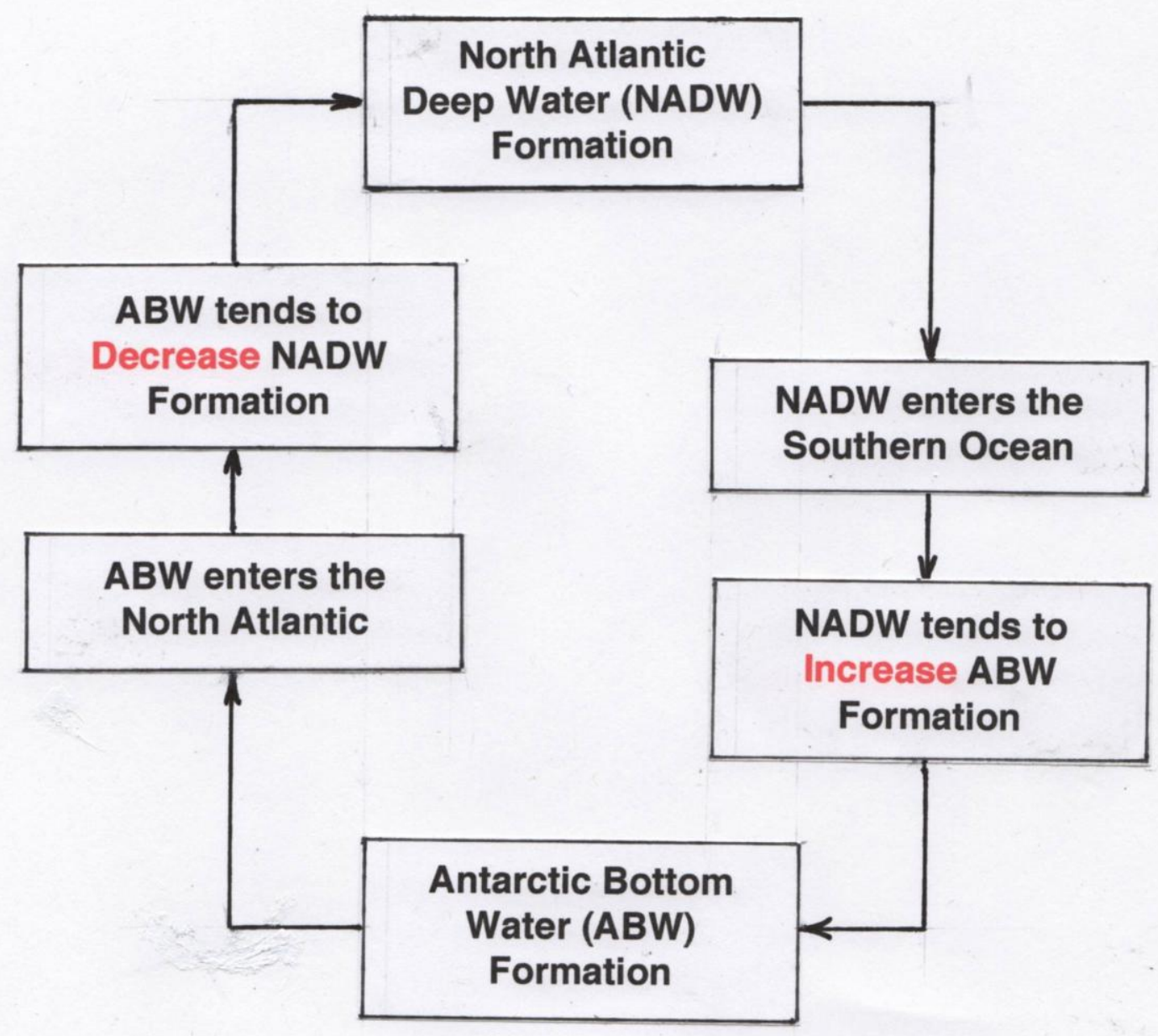

Fig. 2: The bi-polar feedback loop. Delays due to accumulation of NADW in the Southern Ocean and $A B W$ in the deepest oceans enable the 1500 yr oscillation.

Is derived primarily from Gulf Stream water, with a lesser addition from the more saline Mediterranean outflow that rises toward the surface west of the British Isles[8]. The SAC flows northward in the Greenland Sea to replace the sinking NADW (Fig. 1). The strengths of the Drift and Norwegian Current are related directly to the rate of NADW formation. About 10sv of warmer and more saline mixed NADW exits from the Greenland Sea through the Denmark Strait[10]. From there it continues to mix as it goes southward on the western side of the North Atlantic. This warmer mid depth water enters the Southern Ocean and adds to its heat content, thus reducing sea ice formation and increasing ABW formation by exposing more sea surface to the cold winter air in the shallower areas around the continent. 
ABW probably originates mainly over the $6.7 \times 10^{5} \mathrm{~km}^{2}$ continental shelf (Fig. 3) in the central and western parts of the Weddell Sea[10]. Other shallow fringing areas at the edge of the continent may also contribute. In such shallow areas the entire water column can be cooled to the freezing point and made slightly denser by salt rejection during freezing. The sinking surface water is replaced by adjacent low-salinity shallow water at the freezing point. This replacement is quite different from that occurring when water freezes over the deep ocean. There much of the replacement consists of warmer and more saline deep-water rising from intermediate depths. According to Weyl[11], the lower salinity of the colder surface water that sinks in shallow areas makes it relatively more compressible, which aids its downward flow off the continental

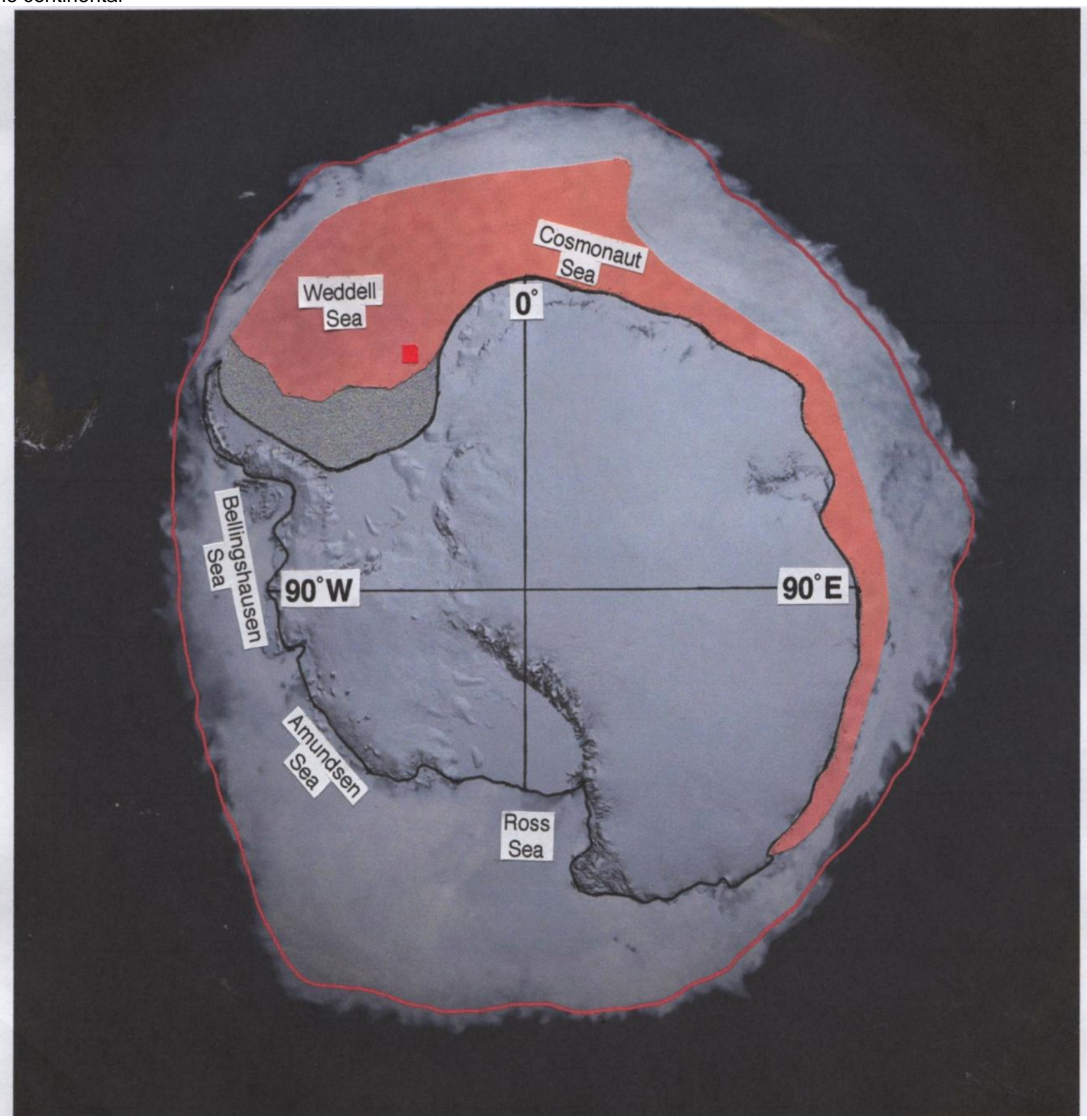

Fig. 3: The Antarctic continent with winter sea ice extent on 15 August, 2014. The orange zone from $135^{\circ} \mathrm{E}$ to $60^{\circ} \mathrm{W}$ reported by Schmidtko et al.[13] is a zone of surface water salinity that is at least $0.2 \mathrm{~g} \mathrm{~kg}^{-1}$ higher than elsewhere. The greater salinity is probably due to upwelling of the slightly warmer and more saline water from the mid depths of the Southern Ocean caused by the northward geostrophic movement of the circumpolar current. The red square marks the farthest south position reached by James Weddell in 1823. Today the Weddell Sea is nearly covered with heavy sea ice even in summer. The grey area is part of the Weddell Sea where the continental shelf has depths less than $1000 \mathrm{~m}$. 
shelf to become denser ABW throughout the world ocean. The rate of ABW formation is proportional to the rate of freezing. The presence of residual sea ice and floating ice shelves in the shallow fringing areas when winter begins tends to insulate the freezing water from the cold atmosphere and therefore diminishes the average rate of freezing and $A B W$ formation. The amount of residual coverage in the shallow areas will depend on the summer oceanic temperatures associated with variable sea ice in the broad deep-water zone around the continent. The area of floating ice shelves may also respond more slowly to such oceanic temperature changes. Therefore the annual amount of ABW formation should be an inverse function of theamount of deep ocean sea ice at winter's end and the resulting amount of residual sea ice over shallow areas at the end of summer.

The analysis of Weyl[12] is the key to the connection between the amount of NADW in the Southern Ocean and the formation rate of $\mathrm{ABW}$ that makes the bi-polar oscillation possible. In this analysis the net amount of deep-water sea ice at winter's end is limited by the amount of warmer mixed NADW in the Southern Ocean. In a narrower zone between latitude $60^{\circ} \mathrm{S}$ and the edge of the continent (Fig. 3) the intermediate-level water rises toward the surface to replace the geostrophic loss of surface water. The surface water is moved northward by the geostrophic (coriolis) effect on the eastward-flowing circumpolar current, and often southward by the same effect on a narrow westwardflowing coastal current. The circumpolar current tends to distribute the upwelling water around the continent, and its heat content has a critical effect on sea ice formation. During summer, the melting of sea ice and glacial ice discharged from the continent stratifies the sea surface layers in a broad zone around the continent. In the winter season, this stratification initially prevents deep vertical convection and enables sea ice to freeze. When a given volume of water freezes, a much larger volume of water is made slightly denser by the rejected salt. Convection begins and this denser water sinks in the form of finger-like accumulations. It is replaced by upward movement of water outside the fingers. At first the replacement water is cold low-salinity water from within the upper part of the stratification. As freezing progresses, the rejected salt weakens the stratification and the fingers extend deeper into the warmer and more saline intermediate level water. Then warmer replacement water upwells to the surface and begins to melt the ice. Eventually shifting patterns of downfingering and upwelling melt the sea ice as fast as new ice can freeze, and no further change occurs in the net amount of sea ice formed over deep water.

Consequently a higher (lower) fractional part of warmer NADW mixed into the Southern Ocean implies a cessation of net freezing of sea ice earlier (later) in the winter season with a thinner (thicker) layer of sea ice and mixed winter water at the end of winter. At the end of summer there would then be lesser (greater) amounts of residual sea ice over the continental shelves, and the following winter a greater (lesser) amount of ABW would form in all the fringing areas. The contributions of ABW forming in the large shallow areas adjacent to the floating ice shelves in the Ross and Weddell Seas are probably of particular importance[13]. In contrast to somewhat warmer conditions of the continental shelf bottom water in the Bellinghausen and Amundsen Seas, the bottom water circulating on the Ross and Weddell continental shelves is already quite close to the freezing point as reported by Schmidtko et al., in their Figures $1 \mathrm{~A}$ and $3 A[13]$. Therefore in the latter two shelf areas little winter cooling to the freezing point would be necessary, and in the process of $A B W$ production variable residual sea ice coverage would have a dominant effect over the initial water temperature.

An increasing or decreasing trend in the fractional content of NADW in the Southern Ocean will depend on the input rate of the mixed mid level NADW from the north, as opposed to losses such as northward geostrophic flow and mixing at the edges of the Southern Ocean.. A similar argument for ABW input versus losses would hold for the composition of the world bottom waters. When the fractional content of NADW in the Southern Ocean is small, the winter sea ice extent is large as it is today. The zonal summer temperatures around the continent are colder, heavy sea ice remains in the fringing areas at summer's end, and shelf ice persists. ABW production and negative feedback to the North Atlantic are then small, thus allowing NADW production to increase as the system oscillation continues.

\section{[1.3] A sinusoidal model}

The continuous feedbacks of both the lower salinity ABW entering the North Atlantic and the higher salinity NADW entering the Southern Ocean suggest a possible sinusoidal form for the oscillation (Fig. 4). The period of the oscillation is inferred from the $1500 \mathrm{yr}$ cyclic variation of ice-rafted sand and sediment from cores beneath the North Atlantic Drift[2]. The time needed to make significant changes in salinity of large volumes of the oceans smooths out the minor random fluctuations of NADW and ABW production, somewhat analogous to the flywheel in a rotating mechanical system. The Bond cycle record is free of significant major glacial melt water effects on the Greenland Sea salinity after about 6000yr BP. But in the deep-sea sediment record there is an absence of data from $\sim 1000 \mathrm{yr}$ BP to present, probably due to loss of the core-top sediment during core recovery. Fortunately in this interval we have historical records of the climate changes.

Within the range of the missing core-top data, observed higher latitude climatic variations are consistent with the oscillating normalized parameters of such a model (Fig. 4), although chaotic short-term climate variations tend to blur the trends[14]. The model is initialized on the early medieval climate optimum at $\sim 1000 \mathrm{yr}$ AD when the Drift flow and NADW formation rate were maximal and ABW presence in the North Atlantic would have been minimal. The transport time is assumed to be relatively small compared to the time to make a significant change in the fractional parts of NADW in the Southern Ocean and ABW in the world bottom water. Therefore at 1000 AD the inflection points on the red and green curves respectively define the most rapid increase of fractional NADW and the most rapid decrease of winter sea ice in the Southern Ocean. The high-latitude climate changes over the last 1000yrs are consistent with the model.

During the early medieval climate optimum, warmth in Scandinavia and the northern British Isles enabled large populations to thrive, and English wines rivaled those of France[14]. The Norse established pastoral colonies on Iceland and southern Greenland, with a Norse presence documented at $79^{\circ} \mathrm{N}$ in the Nares Strait[15] between the polar 
ocean and Baffin Bay. Greenland is also depicted realistically as an island in an archival copy of an older map[16]. The older map, which is now lost, was probably drawn by Bishop Erik Gnupsson after his 1117-1118 AD visit to the Vinland coast of North America[17]. This island depiction implies that the Norse sailed around Greenland in the absence of the thick perennial sea ice that now obstructs navigation along the northern coast.

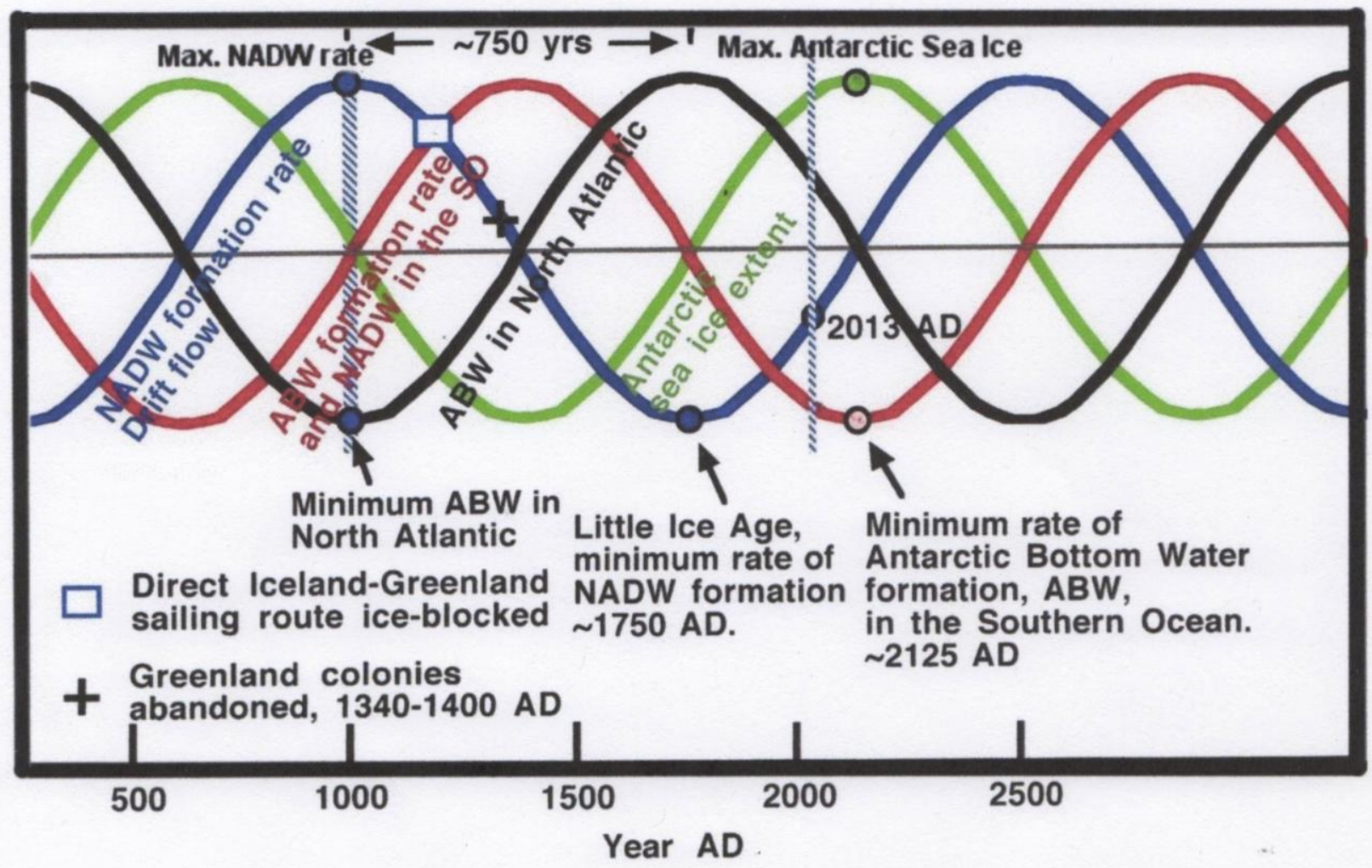

Fig. 4 Phase relationships for normalized parameters in the sinusoidal model. Blue: North Atlantic Deep Water (NADW) formation rate and North Atlantic Drift flow. Black: Fractional Antarctic Bottom Water (ABW) in the North Atlantic. Red: Fractional NADW in mid levels of the Southern Ocean, and ABW formation rate. Green: Antarctic Sea ice area. Unlike systems in which only positive feedback drives the oscillation, the oceanic system uses both negative and positive feedback. The model does not include any modern changes in inputs.

The first indications of cooling appeared in the higher-latitude North Atlantic at about the year 1200 (Fig. 4) when seaice began to clog the usual sailing route between Iceland and Greenland at latitude $65^{\circ} \mathrm{N}[14]$. As the Drift flow and the NADW production continued to decrease, cooling increased, and about 1340 the Norse began to abandon their western colony on Greenland. Sometime soon after 1400, further cooling brought an end to the more southerly eastern colony also[18]. The high-latitude cooling continued and, near the blue curve minimum of NADW formation about 1750 (Fig. 4), the most severe winters in northern North Atlantic regions occurred in the middle of the Little Ice Age. The hardships of northern Europeans have been extensively documented by Lamb[4][14]. Higher-altitude farms in the British Isles and Scandinavia were abandoned and thick ice on the River Thames in London enabled winter ice carnivals. With maximal ABW in the North Atlantic resulting in a weak Drift, sea ice often surrounded Iceland and extended on occasion eastward to northern Scotland and almost to Norway.

A comparison of the model with the record is equally interesting in the Antarctic region. Broecker[6] has noted evidence from CFC-11 tracer measurements indicating that: "The formation rate of ventilated deep water in the Southern Ocean is currently several times smaller than its average for the last deep ocean-mixing cycle (that is $\sim 800 \mathrm{yrs}$ )." Over the last two decades the measurements indicate an average rate of ABW formation of only $4 \mathrm{sv}$. In the model the ABW formation rate (red curve, Fig. 4) is now approaching its predicted minimum at 2125 AD. The preceding 800yrs include the model maximum, and all those red line values are well above present and are quite consistent with Broecker's citation of a much larger average ABW production in the past.

Of particular interest is the model prediction of an approaching maximum in the quantity of Antarctic sea ice (green curve, Fig. 4). This is consistent with the $\sim 2 \%$ increase in the observed maxima of seasonal winter sea ice[19] over the last thirty-four years, with a new historic maximum in 2013. During this interval the winter sea ice area has varied 
widely over a $7.5 \%$ range of $18.0 \times 10^{6} \mathrm{~km}^{2}$ to $19.4 \times 10^{6} \mathrm{~km}^{2}$. Therefore the observed $\sim 2 \%$ increase in frequent maxima from $\sim 19.0 \times 10^{6} \mathrm{~km}^{2}$ in 1980 to $\sim 19.4 \times 10^{6} \mathrm{~km}^{2}$ in 2013 may not be statistically significant. Nevertheless the large seasonal Antarctic sea ice area that has been sustained near a historical record maximum contrasts with the $~ 8 \%$ decrease in area of Arctic winter sea ice since 1980[20], which is presumably caused by high latitude $\mathrm{CO}_{2}$ warming. It is of interest to examine possible reasons for the persistence of the large Antarctic winter sea ice area.

A warming of the remnant of the winter mixed layer above the statistically significant level from 1975 to 2012 in several areas in a broad zone around the continent has been reported by Schmidtko et al.[13]. But in a narrower zone adjacent to the continent most areas show little or no statistically significant warming. Even if warming occurred in this narrow zone, the direct effect of a warming would of course not have caused the sea ice increase. However, a related increase in shelf ice melting might have reduced surface salinity and increased the surface stratification that favors the freezing of sea ice. Such a warming has been reported over the continental shelf[13] in the Bellingshausen and Amundson Seas, but without significant salinity change there although a freshening of the coastal water in the Ross Sea and adjacent coast has occurred. But on the opposite side of the continent over a longitude range of $195^{\circ}$ there is little indication of significant salinity decrease from 1975 to 2012 in the winter water near the coast as shown in Figure $3 E$ of Schmidtko et al.[13]. The Weddell Sea gyre has small areas of both slightly increasing and decreasing salinity. Consequently it seems unlikely that a small amount of shelf ice melting in the Pacific Ocean sector without significant melting in the Atlantic and Indian Ocean sectors would explain an increase in maxima of winter sea ice area since 1975.

A more probable explanation involves the decrease in fractional content of the warmer NADW in the Southern Ocean suggested by the model. In part of a narrow zone (Fig. 3) extending westward from longitude $135^{\circ} \mathrm{E}$ to the Weddell Sea at $60^{\circ} \mathrm{W}$, the winter water salinity is at least $0.2 \mathrm{gkg}^{-1}$ higher than elsewhere[13]. This zone expands to include the Cosmonaut Sea and the Weddell Sea gyre, and is likely the result of the geostrophic upwelling of the slightly warmer and more saline mid depth Southern Ocean water. In the model the decrease in the fractional part of NADW in the Southern Ocean since 1975 is only about $1.6 \%$ of the total normalized amplitude, which is small relative to the observed random variations of up to $7.5 \%$ in the winter sea ice area over the last 30yrs[19]. Therefore the slight 35yr reduction of heat content of the mid depth water of the Southern Ocean as inferred from the model would be consistent with a small increase in winter sea ice area that is almost masked by larger $7.5 \%$ random variations of factors that also influence the area of winter sea ice. However on a time scale of centuries the model suggests a much smaller area and thickness of winter sea ice in the past. We do not know the sea ice area in winter or summer for more distant past times, but one historical fact may be relevant. In 1823 James Weddell sailed to $74^{\circ} 15^{\prime} \mathrm{S}-34^{\circ} \mathrm{W}$ (red square, Fig. 3) off the coast in the Weddell Sea[21], a voyage that would probably not be possible in a wooden ship in today's year-round and nearly ice-filled Weddell Sea. In that year the model implies that the winter sea ice was less than today by $28 \%$ of the total normalized variation. The resulting lesser amount of summer sea ice may have made Weddell's voyage possible.

\section{[2] FUTURE CLIMATE IMPLICATIONS}

Although the model predicts another northern high-latitude climate optimum about $2500 \mathrm{AD}$, the unusually warm temperatures may arrive earlier because modern society's activities are accelerating the increase in NADW formation and SAC flow. In the first part of the 20th century, the late winter open water due to SAC flow in April typically extended north to about $76.6^{\circ} \mathrm{N}$ latitude, the southern cape of Spitsbergen[4]. But in recent years the usual open-water SAC flow in late winter has reached $400 \mathrm{~km}$ farther northward to Spitsbergen's north coast and beyond (Fig. 5). In the coldest part of the winter of 2014 in mid February the maximum rate of NADW formation extended the open water of the SAC flow beyond latitude $83^{\circ} \mathrm{N}$ (Fig. 6), causing a brief partial obstruction of the southward flow of polar sea ice into the Fram Strait between Greenland and Spitsbergen.

Most of the salinity increase implied by the greater SAC flow in recent decades has probably been caused by a more saline Drift due to an artificial increase in the saline Mediterranean outflow. I estimate that Mediterranean river inflows formerly compensated for almost $30 \%$ of its net evaporation losses of about $35,000 \mathrm{~m}^{3} \mathrm{sec}^{-1}$. But beginning about 1950 , most of the flows of major Mediterranean rivers have been diverted for irrigation. Consequently the Mediterranean salinity has begun a rapid rise that will continue for at least another century, as suggested by a single-basin Mediterranean e-fold mixing time of about 120 years. In the last 60yrs the measured salinity of the deep western Mediterranean has increased by about $0.05 \%$ (news item, Science, 1998, v. 279, p. 483). Salinity would be greater at the outflow depth of $<300 \mathrm{~m}$. The salinity difference between outgoing Mediterranean water and the incoming Atlantic across the central part of the Gibraltar Strait is about $1.7 \%$. The $0.05 \%$ is therefore equivalent to at least a $\sim 2.9 \%$ increase in the density difference between Atlantic and Mediterranean water that drives the outflow at the Gibraltar sill. Consequently, the outflow rate is likewise increasing and would be adding more salt to the Drift and the Greenland Sea[8][22]. The more rapid outflow would have greater turbulent mixing and should therefore equilibrate at a shallower depth and mix more efficiently into the Drift. The modern northward subsurface flow rates at latitude $54.5^{\circ} \mathrm{N}$ as calculated by Greatbatch and Xu[9] together with the transect of Reid[8] suggest that most of the Mediterranean outflow influence is confined to the Norwegian Current. The density difference increase of $>2.9 \%$ has therefore apparently caused a salinity increase in the Greenland Sea, greater SAC flow, and the brief partial obstruction of southward polar ocean flow in February of 2014.

In the next few decades, the salinity of the Mediterranean outflow and the Greenland Sea will continue to increase. Although other variables influence the SAC flow, eventually blockages of polar flow into the Fram Strait in midwinter may become complete. If so and consistent with the historical record of $1118 \mathrm{AD}$, annual pulses of warmer and more saline Atlantic water from the SAC flow will again penetrate the coastal sea north of Greenland and remove the perennial sea ice. If a sufficient flow of that denser water replaces the lower density polar water moving southward 
through the Nares Strait, the near-surface stratification in Baffin Bay could be destroyed and all of the sea surface west of Greenland would become. warmer and ice-free in winter. The open water there could cause a major change in meteorological conditions and a large increase in regional precipitation. This would favor possible ice sheet growth in the glacial nucleation areas of the eastern Canadian Arctic[23].

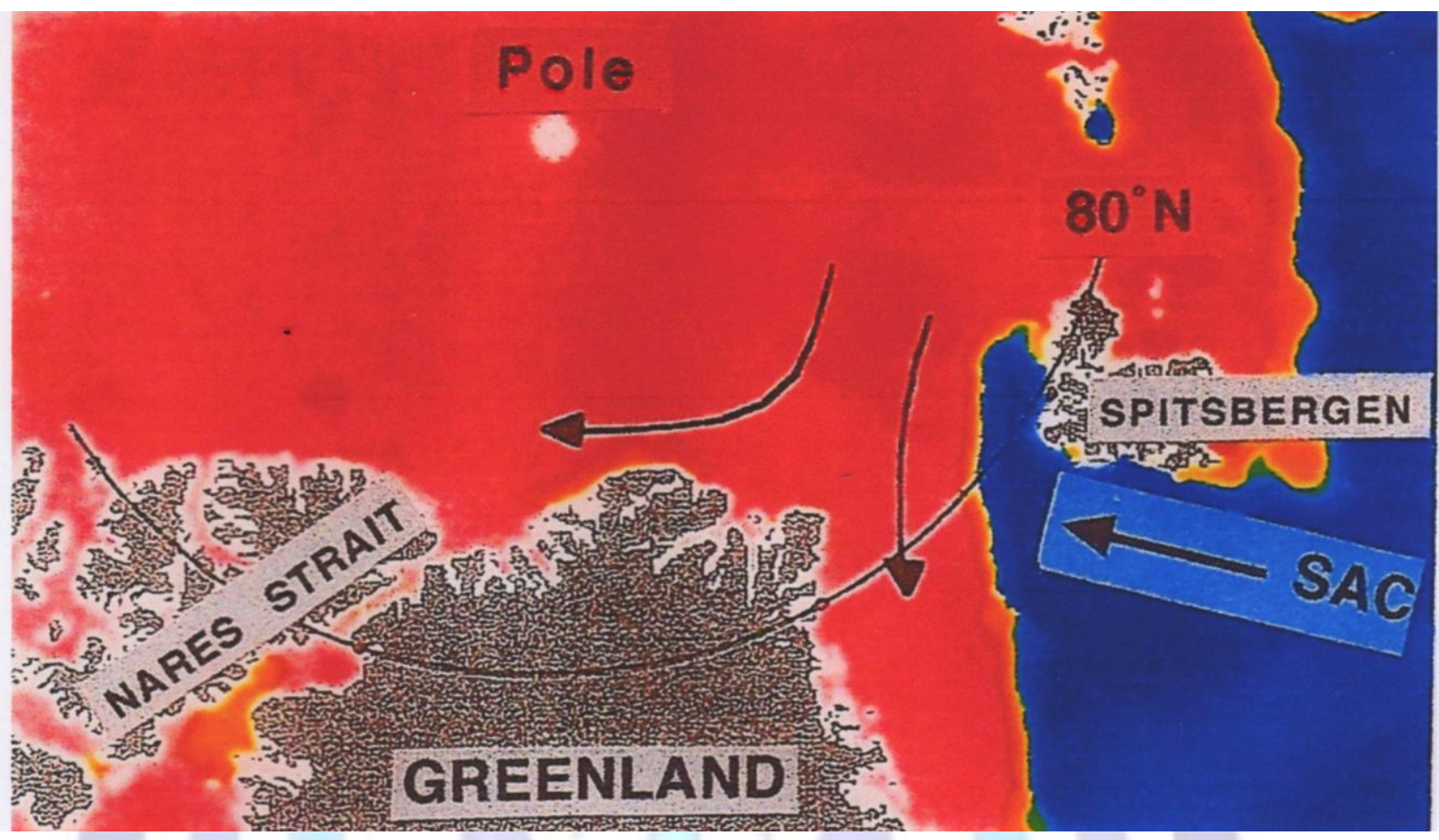

Fig. 5 Polar Sea ice (false red color) showing movement of sea ice near northern Greenland and the open water of the Spitsbergen-Atlantic Current (SAC) north of latitude $80^{\circ}$ on 20 March, 2013. Source: http://www.seaice.dk/latest-ice.html

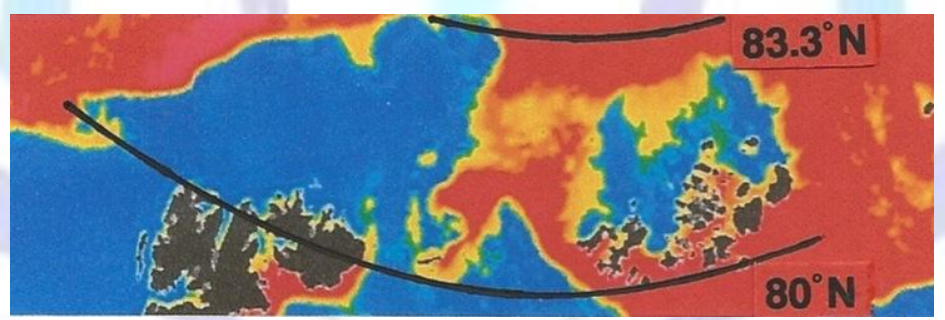

Fig. 6 Polar sea ice (false red color) showing maximum northward extension of the open water of the Spitsbergen-Atlantic Current (SAC) beyond $83^{\circ} \mathrm{N}$ on 18 February, 2014. Spitsbergen on left, Franz Joseph Islands on right. Source: http://www.seaice.dk/iomasa/amsr/thin/today

\section{REFERENCES CITED}

[1] Broecker, W.S., 1991, The great ocean conveyor: Oceanography, v. 4, 79-90.

[2] Bond, G., W. Showers, M. Cheseby, R. Lotti, P. Almasi, P. deMenocal, P. Priore, H. Cullen, I. Hadjas, and G. Bonani,1997, A pervasive millennial-scale cycle in North Atlantic Holocene and glacial climates: Science, v. 278, p. 1257-1266.

[3] Seppä, H.G. and H.B.J. Birks, 2001, July mean temperature and annual precipitation trends during the Holocene in the Fennoscandian tree-line area: pollen-based climate reconstructions: The Holocene, v. 11, 527-537.

[4] Lamb, H.H., 1972, Climate Present Past and Future: v. 1, Metheun \& Co, Ltd., London, p. 338, 410-464.

[5] Miller, G.H., A.. Geirsdottir, Y. Zhong, D.J. Larson, B.L. Otto-Bliesner, M.M. Holland, D.A. Bailey, K.A. Refsnider,S.J. Lehman, J.R. Southon, C. Anderson, H. Björnsson, T. Thordarson, 2012, Abrupt onset of the Little Ice Age triggered by volcanism and sustained by sea-ice/ocean feedbacks: Geophysical Research Letters, v. 39, L02708,doi:1029/2011GL050168.

[6] Broecker, W.S.., 2000, Was a change in thermohaline circulation responsible for the Little Ice Age?: Proceedings National Academy of Science, v. 97(4), p. 1339-1342.

[7] Wright, J.L., 1970, Northward transport of Antarctic Bottom Water in the western Atlantic Ocean: Deep-Sea Research, v. 17, p. $367-371$. 
[8] Reid, J.L., 1979, On the contribution of the Mediterranean Sea outflow to the Norwegian- Greenland Sea: Deep-Sea Research, v. 26, p. 1199-1223.

[9] Greatbatch, R.J., and J. Xu, 1993, On the transport of volume and heat through sections across the North Atlantic: Climatology and the pentads 1955-1959, 1970-1974: J. Geophysical Research, v. 98, p. 10126-10143.

[10] Worthington, L.V., 1976, On the North Atlantic Circulation: No. 6, The Johns Hopkins oceanographic studies: Johns Hopkins University Press, Baltimore, p. 31.

[11] Weyl, P.K., 1969, Equivalent salinity, a new oceanographic parameter for the study of vertical motion in the sea: Deep-Sea Research, v. 16, p. 513-523.

[12] Weyl, P.K., 1968, The role of the oceans in climate change: A theory of the ice ages, in: Causes of Climate Change:J.M. Mitchell (ed.), Meteorological Monographs 8(No.30), American Meteorological Society, p. 37-62.

[13] Schmidtko, S., K.J. Heywood, A.F. Thompson, S. Aoki, 2014, Multidecadal warming of Antarctic waters:

Science,v. 346, p. 1227-1231.

[14] Lamb, H.H., 1995, Climate History and the Modern World: second edition, Routledge, London, p. 179, 187, $211-241$.

[15] Schledermann, P., 2000, Ellesmere: Vikings in the far north, in Vikings: The North Atlantic Saga, W.W. Fitzhugh and

E.I. Ward, eds, Smithsonian Institution Press, Washington, p. 248-256.

[16] Ingstad, H., 1969, Westward to Vinland: St. Martins Press: New York, p. 33, 85-89.

[17] Skelton, T.A., T.E. Marston, and G.D. Painter, 1965, The Vinland Map and the Tartar Relation: Yale University Press, New Haven, p. 224-255.

[18] Seaver, K.A., 1996, The Frozen Echo: Greenland and the Exploration of North America AD 1000-1500: Stanford University Press, Stanford, 113-158.

[19] NASA, 2014, http://earthobservatory.nasa.gov/Features/WorldOfChange/sea ice south.php

[20] Cryosphere Today, 2014, http://arctic.atmos.uiuc.edu/cryosphere/

[21] NGS, 1981, National Geographic Society Atlas of the World, $5^{\text {th }}$ edition, p. 220.

[22] Hernández-Molina, F.J., E. Llave, B. Preu, G. Ercilla, A. Fontan, M. Bruno, N. Serra, J.J. Gomiz, R.E. Brackenridge,F.J. Sierro, D.A.V. Stow, M. Garcia, C. Juan, N. Sandoval, and A. Amaiz, 2014, Contourite processes associated with the Mediterranean Outflow Water after its exit from the Strait of Gibraltar: Global and conceptual implications:Geology, v. 42, p. 227-230.

[23] Johnson, R.G.., 1997, Ice age initiation by an ocean-atmospheric circulation change in the Labrador Sea: Earth and Planetary Science Letters 148, 367-379. 